PERM JOURNAL OF PETROLEUM AND MINING ENGINEERING ВЕСТНИК ПНИПУ. ГЕОЛОГИЯ. НЕФТЕТАЗОВОЕ И ГОРНОЕ ДЕЛО

ISSN 2224-9923

Volume/Tom 19 №3 2019

$\mathrm{http} / / /$ vestnik pstu.ru/geo/

UDC 622.276:622.24

Article / Статья

(C) PNRPU / ПНИПУ, 2019

\title{
ESTIMATED EFFICIENCY OF RADIAL DRILLING TECHNOLOGY FOR TOURNAISIAN PRODUCTION ZONES OF THE PERM REGION
}

\section{Aleksandr A. Kochnev, Sergey V. Galkin ${ }^{1}$}

PermNIPIneft branch of LUKOIL-Engineering LLC in Perm (29 Sovetskoy Armii st., Perm, 614066, Russian Federation)

${ }^{1}$ Perm National Research Polytechnic University (29 Komsomolskiy av., Perm, 614990, Russian Federation)

\section{ПРОГНОЗНАЯ ОЦЕНКА ЭФФЕКТИВНОСТИ ТЕХНОЛОГИИ РАДИАЛЬНОГО БУРЕНИЯ ДЛЯ ТУРНЕЙСКИХ ЭКСПЛУАТАЦИОННЫХ ОБЪЕКТОВ ПЛАТФОРМЕННОЙ ЧАСТИ ПЕРМСКОГО КРАЯ}

\section{А.А. Кочнев, С.В. Галкин ${ }^{1}$}

Филиал ООО «ЛУКОЙЛ-Инжиниринг» «ПермНИПИнефть» в г. Перми (614066, Россия, г. Пермь, ул. Советской Армии, 29) ${ }^{1}$ Пермский национальный исследовательский политехнический университет (614990, Россия, г. Пермь, Комсомольский проспект, 29) Received / Получена: 06.12.2018. Accepted / Принята: 01.08.2019. Published / Опубликована: 27.09.2019

\section{Keywords:}

radial drilling, acid treatment, geological and technical operations, oil production rate, carbonate reservoir, discriminant analysis, statistical model, oil recovery enhancement, hydrodynamic modelling, remaining oil, reservoir, probabilistic assessment, correlation ratio, production zone, efficiency forecast.
The reservoirs of the Tournaisian deposits in the Perm Region are characterized by high heterogeneity of the geological section, low thickness and relatively low well productivity. For the rational development of such deposits intended to enhance the oil recovery ratio, various well interventions are required. The paper compares the effectiveness of such lowcost operations as acid treatments and radial drilling.

It further considers the radial drilling technology in detail. Radial drilling operations at the Tournaisian deposits of the Perm Region oilfields are analysed. To assess the projected oil production, a graph of the actual decline in the incremental oil production from the time of operation over the years has been plotted.

The paper presents the methods of estimating the well intervention effectiveness. The main method is hydrodynamic modelling. However, it has significant drawbacks in predicting the effectiveness of radial drilling technology. In the authors' opinion, the optimal well intervention effectiveness forecast methods are statistical methods taking the complex impact of geological and technological parameters into account. In the course of the research, the Student's $t$-test was used to identify the main geological and technological parameters that have an impact on the efficiency of radial drilling. With the identified parameters and the linear discriminant analysis method, a predictive model for estimating an increase in oil production for the first year after the operation was built. For the wells selected as the training and test samples, the error of the oil output growth forecast for the first year after the operation was assessed. The errors in the forecast calculations were then compared to the forecast error estimation obtained using the hydrodynamic model. The output of the study is the developed method for determining the total incremental production using radial drilling technology.

Коллекторы турнейских отложений нефтяных залежей Пермского края характеризуются высокой неоднородностью геологического разреза, малыми толщинами и невысокой производительностью скважин. Для их рациональной разработки с целью повышения нефтеотдачи пластов широко применяются геолого-технические мероприятия. В работе проведено сравнение эффективности малозатратных геолого-технических мероприятий кислотных обработок и радиального бурения

Подробно рассмотрена технология радиального бурения. Приведен анализ мероприятий по радиальному бурению, выполненных на турнейских объектах месторождений Пермского края. По фактическим данным построен график динамики падения дополнительной добычи нефти от мероприятия по годам, который можно использовать для оценки прогнозной добычи нефти.

Представлены методики прогноза эффективности геолого-технических мероприятий. Основным методом является гидродинамическое моделирование. Однако у метода существуют значительные недостатки при прогнозе эффективности применения технологии радиального бурения. По мнению авторов, наиболее оптимальным для прогноза эффективности технологических мероприятий является использование статистических методов, что позволяет учитывать комплексное влияние геолого-технологических параметров. В ходе исследования с помощью $t$-критерия Стьюдента выявлены основные геолого-технологические параметры, оказывающие влияние на эффективность радиального бурения.

На основе выявленных параметров методом линейного дискриминантного анализа построена прогнозная модель оценки прироста дебита нефти в первый год после мероприятия. На скважинах обучающей и тестовой выборки проведена оценка погрешности прогноза прироста дебита нефти в первый год после мероприятия. Сопоставлены погрешности прогнозных расчетов с погрешностью прогноза при исследовании гидродинамической модели. Результатом исследований является разработанная методика определения общей дополнительной добычи от применения технологии радиального бурения.

\footnotetext{
Aleksandr A. Kochnev - Engineer (tel.: +007 34223364 14, e-mail: sashakoch93@gmail.com).

Sergey V. Galkin (Author ID in Scopus: 36711675500) - Doctor of Geology and Mineralogy, Professor, Dean of the Department of Mining and Oil (tel.: +007 3422198000,
} e-mail: doc_galkin@mail.ru). The contact person for correspondence.

Кочнев Александр Александрович - инженер (тел.: +007 34223364 14, e-mail: sashakoch93@gmail.com). Контактное лицо для переписки. Галкин Сергей Владиславович - доктор геолого-минералогических наук, профессор, декан горно-нефтяного факультета (тел.: +007 3422198000 , e-mail: doc_galkin@mail.ru). 


\section{Introduction}

In the structure of the remaining oil in place in the Perm Region, Tournaisian and Fammenian carbonate deposits account for their major part of $44 \%$ (222.7 out of 506.2 million tons of oil). In the platform part of the Perm Region, these deposits are developed at 130 production zones with over $80 \%$ of the deposits located solely in the Tournaisian strata. Hereinafter, all the Tournaisian and Fammenian deposits in the studied territory are referred to as the "T-formation". The permeability values used for estimation of the oil reserves in the $\mathrm{T}$-formation range from 3 to $676 \mathrm{mD}$, while formation oil viscosity varies from 0.8 to $87 \mathrm{mPa} \cdot \mathrm{s}$.

\section{Characteristics of tournaisian reservoirs of the Perm Region oilfields}

In the platform part of the Perm Region, the T-formation reservoirs are mainly represented by organogenic and detrital, fine detrital and lumpy algal limestones. The core material from the oil-saturated part of the geological section has been studied, in particular, using X-ray tomography to visualize the structure of the rock porous space [1-3]. In carbonate reservoirs, the $\mathrm{X}$-ray tomography is used as a method of visualizing the cavernosity and fracturing of rocks in high definition [4-7]. The core material analysis combined with hydrodynamic well testing done with the method described in papers $[8,9]$ has shown that the Tournaisian reservoirs in the platform part of the Perm Region mainly belong to the porous (granular) type. The presence of fractures is generally untypical of these production zones.

Core analysis has shown that the open porosity $\left(K_{\mathrm{p}}\right)$ of the Tournaisian reservoirs falls within a broad range (from 8 to $19 \%$ ) with the average value of $12 \%$. Low-porosity reservoirs $\left(K_{\mathrm{p}}<12 \%\right)$ belong mainly to the granular type (fig. $1, a$ ), while in more porous ones the void space also includes dissolved cavities (see. fig. 1,b).

The reservoirs of the Tournaisian deposits are characterized by high heterogeneity of the geological section, low thickness and, as a rule, not very high well productivity. The field experience shows that at all the stages of oilfield development the permeability of the bottomhole area deteriorates due to the sealing of rocks, increasing water saturation followed by the reduction of phase permeability for oil, salting and paraffin buildup [10]. In such conditions, the most cost-efficient well intervention techniques for carbonate reservoirs are acid treatment and radial drilling [11].
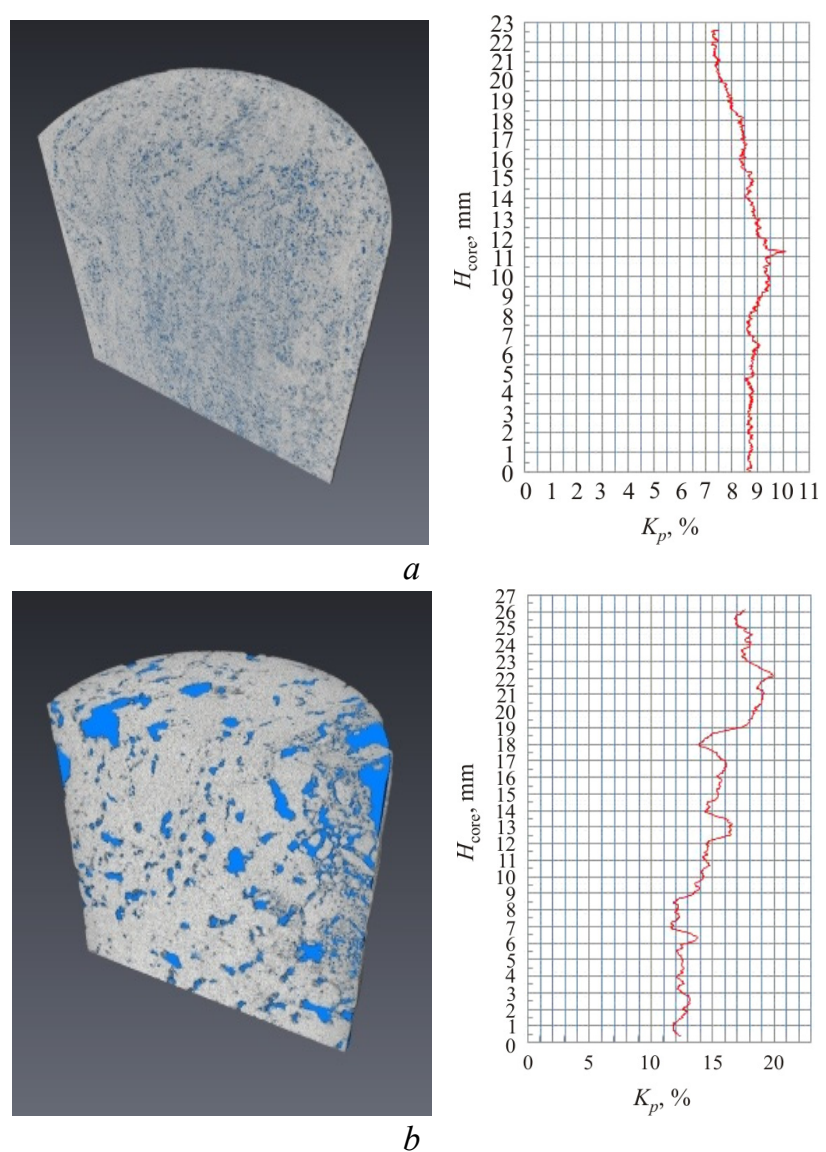

Fig. 1. Void space structure of the Tournaisian reservoirs of porous $(a)$ and cavernous and porous $(b)$ types based on core X-ray tomography

Acid treatment is one of the most common well interventions used on carbonate reservoirs to recover and improve the fluid flow in the bottomhole area, increasing productivity of the production wells and injectivity profile of the injection wells [12]. The radial drilling technology means, in this case, drilling horizontal radial channels of a smaller diameter with a jet nozzle. The channel length does not exceed $100 \mathrm{~m}$, while their number usually ranges from 2 to 4 . The radial drilling technology is considered not only to improve the productivity of the wells but also to engage the previously undrained reserves into the production, materially expanding the displacement process $[13,14]$. 


\section{Comparing the efficiency of acid treatment and radial drilling technologies}

In the course of study, the technological efficiency of acid treatment and radial drilling in respect of the Tournaisian formations of the Perm Region was compared. The results of employing acid treatment to the carbonate formations in the Perm Region are provided in paper [15], while the summary of international experience is provided in papers [16-20]. In foreign literature, acid treatment efficiency studies focus more on the composition of rocks, e.g. carbonate content, clay particles content, cement type and port space structure [18-20].

Table 1 presents the results of comparing the efficiency of acid treatment and radial drilling for the Tournaisian formations of the Perm Region fields. The number of wells covered by the analysis: acid treatment -148 wells, radial drilling -115 wells.

The comparison was carried out using Student's t-test. Table 1 shows the average values of the efficiency indicators (for acid treatment and radial drilling, respectively), the t-score values and the achievable level of $p$. In respect of the considered indicators of the Tournaisian formations, the efficiency of the radial drilling technology is statistically significant $(p<0.05)$ and exceeds that of the acid treatment.

Thus, the technological effect of the radial drilling varies in a broad range and mostly depends on the geotechnical conditions of the method implementation. At the same time, by this moment there are no formalized efficiency criteria for the radial drilling technology [21].

There is a number of purely technical aspects that complicate the implementation of radial drilling technology. First of all, the problems were caused by significant hydrodynamic loads on jet nozzles (up to $100 \mathrm{MPa}$ ) arising from high-speed jets (up to $400 \mathrm{~m} / \mathrm{sec}$ ) of flush fluid. That creates a large area of penetration of the emulsion filtrate with non-stationary rheological characteristics [22] in the area of destruction. The second important technical issue is the impossibility to exercise prompt control over the trajectory of the channels due to low bending stiffness of the assembly and different densities of the jet-broken rocks. In exceptional cases, this can result in the preformation by the channels of the water formations, which is absolutely inadmissible. All of the above points to the necessity of careful selection of the wells based primarily of their geological and physical characteristics.

Table 1

Comparison of the efficiency of the radial drilling methods and acid treatment for the Tournaisian formations of the Perm Region

\begin{tabular}{|l|c|c|c|c|}
\hline \multicolumn{1}{|c|}{ Parameter } & $\begin{array}{c}\text { Acid } \\
\text { treatment, } \\
\text { average } \\
\text { value }\end{array}$ & $\begin{array}{c}\text { Radial } \\
\text { Drilling, } \\
\text { average } \\
\text { value }\end{array}$ & $t$ & $p$ \\
\hline $\begin{array}{l}\text { Time of operation } \\
\text { with operational } \\
\text { benefit, days }\end{array}$ & 883.7 & 1144.1 & -1.94 & 0.05 \\
\hline $\begin{array}{l}\text { Average daily } \\
\text { incremental } \\
\text { production, } \\
\text { tons per day }\end{array}$ & 2.3 & 3.3 & -4.02 & $\begin{array}{c}\text { Less than } \\
0.01\end{array}$ \\
\hline $\begin{array}{l}\text { Accumulated } \\
\text { incremental oil } \\
\text { production, tons }\end{array}$ & 2781.7 & 4473.2 & -2.63 & $\begin{array}{c}\text { Less than } \\
0.01\end{array}$ \\
\hline
\end{tabular}

Developing statistical models for projecting the efficiency of radial drilling for the Tournaisian formations of the Perm Region

Due to their fracturing, the Tournaisian formations feature significant incremental production during the first year after intervention. However, the fractures tend to collapse in the production process due to the pressure drop, resulting in a sharp decline of the effect [23-26]. Both Russian and foreign literature pays much attention to the impact of fracturing on the field development efficiency [27-30].

In paper [31], a forecast crossplot was developed based on the statistical analysis of technological effect's dynamics in respect of the radial drilling. For this crossplot (Fig. 2), the wells were divided into classes based on incremental production for tracking the effect decline for each well group. Thus, knowing the value of incremental production for the first year, the decline of production with time can be forecasted by means of extrapolation.

When used at the stage of selecting candidate wells for the radial drilling technology, this crossplot requires the assessment of the amount of incremental oil production in the first year after the well intervention $\left(\Delta q_{\mathrm{n}}\right)$, which is decisive for the production dynamics over time. 


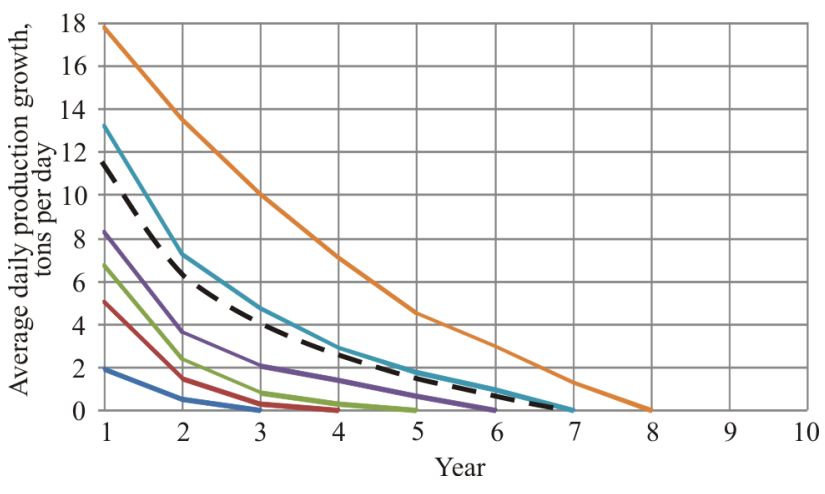

- Class 1 (incremental production of 50-500 tons) - Class 2 (incremental production of 500-1000 tons) Class 3 (incremental production of 1000-2000 tons) - Class 4 (incremental production of 2000-4000 tons) Class 5 (incremental production of 4000-8000 tons) Class 6 (incremental production of over 8000 tons)

- Forecast curve

Fig 2. Crossplot of evaluation of the technological effect of the radial drilling technology on the Tournaisian formations [31]

At the moment, the primary method for assessing the effectiveness of well interventions for oil and gas producing companies of the Perm Region, including radial drilling, is the geological and hydrodynamic modelling [32-33]. At the same time, it is quite hard to develop a fluid flow model of the carbonate reservoirs that would accommodate the impact of the fracturing component on the fluid flow, which materially impairs the models' reliability [34-36].

As applicable to the radial drilling technology, the efficiency of geological and hydrodynamic modelling continues to decline as radial channels of $100 \mathrm{~m}$ will be represented by one or two cells in the model. This being said, even this cell of the model can be characterized only in subjective and quantitative terms by the channel connectivity with the formation $(\varphi)$ and a screen factor $(S)$. In practice, the $\varphi$-value is based on the necessary production of fluid after the well intervention, and the skin-factor is introduced based on the well tests, though they do not provide reliable results for all the wells. Therefore, the total error magnitude of this approach is quite high.

A possible alternative to forecasting the efficiency of well interventions can be the use of displacement characteristics when the technological parameters are extrapolated with account of possible incremental production. However, in this case, at least the impact of geological and technical parameters of the given wells is not taken into account, which will obviously reduce the efficiency of well interventions for them.

Given the above, in the opinion of the authors, the statistical methods are more suitable for the evaluation of the radial drilling efficiency. They are applied to the production formations treated with the radial drilling technology to identify the geological and technical indicators making the greatest impact on the well intervention efficiency. Such an approach is suitable for express efficiency analysis of the technology, while the forecasting model makes it possible to rank the wells by the priority of radial drilling use [37-40]. The papers $[41,42]$ describe the methodology and provide successful examples of the statistical modelling results as applicable to the forecast of various well interventions.

The incremental oil production during the first year after the radial drilling $\left(\Delta q_{\mathrm{n}}\right)$ is ultimately determined by a set of indicators of well interventions. The method chosen to evaluate the statistical impact of the indicators of the well intervention efficiency is linear discriminative analysis (LDA). The methodological aspects of evaluating the technological effect of well interventions using LDA method are discussed in paper [42].

For the LDA implementation, the wells that had not undergone acid treatment before radial drilling (for 15 years). The statistical analysis based on Student's t-test has shown a significant difference in the efficiency of the radial drilling without prior acid treatment and after it both in respect of incremental oil production ( $\mathrm{t}$-test $=2.03 ; \mathrm{p}=0.04)$, and average daily growth (t-test $=2.37 ; \mathrm{p}=0.02$ ). For the Tournaisian formations, the acid treatment performed within 1-15 years prior to the radial drilling, reduce the $\Delta q_{\mathrm{n}}$ value by 0.8 tons per day on average. As preliminary acid treatment takes away a part of the potential increments production, such wells were excluded from the statistical analysis.

Moreover, wells that underwent radial drilling in the new perforation interval were also excluded from the analysis scope, since in this case the increment is achieved primarily by involving new reservoir pay zones. As a result, the analysis covered 41 wells treated with the radial drilling technology in the current perforation interval. At the same time, the analyzed wells were also classified by the efficiency of the radial drilling results based on the cutoff value $\left(\Delta q_{\mathrm{n}}\right)$. 
With account of the geological and technical characteristics and the calculated increment range, the cutoff efficiency value was set to 5.5 tons per day. As a result, 12 wells were classified as having less effective well interventions $\left(\Delta q_{\mathrm{n}}<5.5\right.$ tons per day), and 27 wells were identified to have more effective well interventions $\left(\Delta q_{\mathrm{n}}>5.5\right.$ tons per day). The LDA method foresees finding linear combinations of the attributes that define the two classes best.

As a result of LDA, the parameters that have the highest impact on $\Delta q_{\mathrm{n}}$ were identified and the following Linear Discriminant Functions (LDF) was obtained:

$$
\begin{gathered}
Z=-0,22 \cdot q_{n}+10,3 \cdot K_{\text {sand }}-0,06 \cdot K_{\text {est }}- \\
-0,0063 \cdot \mu_{n}+0,176 \cdot \rho_{\text {chan }}+0,0056 \cdot \chi-0,76 \cdot h_{\text {intl }}+ \\
+0,0013 \cdot S-3,41 \text { at } R=0,60
\end{gathered}
$$

where $q_{\mathrm{n}}$ is oil production before the intervention; $K_{\text {sand }}$ is net-to-gross ratio; $\mu_{\mathrm{n}}$ is oil viscosity; $\rho_{\text {chan }}$ is channel density; $\chi$ is piezoconductivity; $h_{\text {intl }}$ is the oilsaturated layer thickness; $S$ is skin factor.

In general, the LDA method correctly identifies 25 out of 27 formations (93\%) with an increment below 5.5 tons per day and 9 out of 14 (64\%) with the increment above 5.5 tons per day.

In this LDF, the highest impact on the classification results was rendered by the net-to-gross ratio $K_{\text {sand }}$ (the standardized rate is $R_{s t}=0.90$ ), piezoconductivity $\chi\left(R_{s t}=0.66\right)$ and oil production before the intervention $q_{\mathrm{n}}\left(R_{s t}=-0.46\right)$, and to a lesser extent, by the sand-to-shale ratio

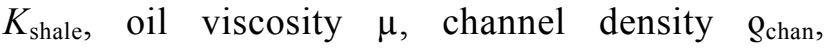
skin factor $S$, and specific thickness of the oilsaturated layer $h_{\text {intl }}$.

The higher is the $Z$ value in this LDF, the higher is the probability of a successful well intervention $\left(\Delta q_{\mathrm{n}}>5.5\right.$ tons per day). To proceed to the probabilistic estimate, the dependence of the probability of classification as a more effective well intervention $P(Z)$ on the estimates characteristic $Z$ (Fig. 3) shall be used.

After the probability for the training wells samples has been calculated, it shall be compared with the actual oil production growth. Fig. 4 shows the dependence of $\Delta q_{\mathrm{n}}$ on the probabilistic estimate $P(Z)$, which can be approximated with the following linear function:

$$
\Delta q_{\mathrm{n}}=6,2 \cdot P(Z)+3,216 \text { with } r=0,99 .
$$

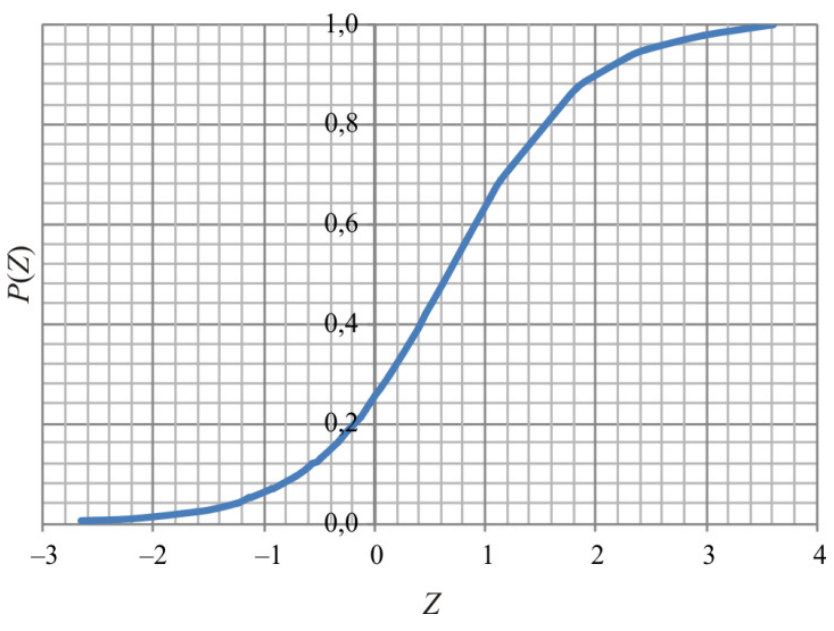

Fig. 3. Probability of the oil production increment in the first year based on the estimated LDF

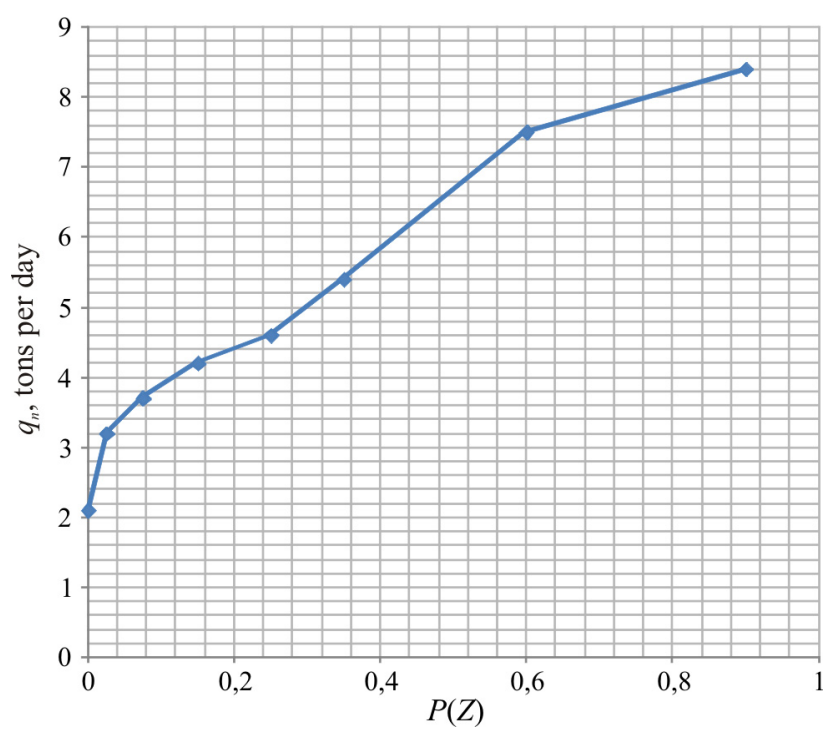

Fig. 4. Dependence of the average daily oil production in the first year after radial drilling on the probability to be classified as a more successful intervention

Based on the dependency $\Delta q_{\mathrm{n}}=f(P(Z))$, the average daily growth for the first year after the radial drilling can be forecasted. To verify the method reliability, the values of $\Delta q_{\mathrm{n}}$ were calculated for the training sample, and then, in comparison to the actual values, the estimated errors were determined.

Fig. 5, a presents the graph of minimal disparities for the LDA method compared to those of the calculations based on hydrodynamic models. The comparison was carried out for the training sample wells. When the LDA-based methodology is used, the forecast disparities range from -5.6 (overstatement of $\Delta q_{\mathrm{n}}$ ) to +4.9 tons per day (understatement of $\Delta q_{\mathrm{n}}$ ). At that, over a half of the wells $(68 \%-28$ wells $)$ got into the error interval from -2 to 2 tons per day. The class with a disparity of over 4 tons per day comprised 4 wells. 

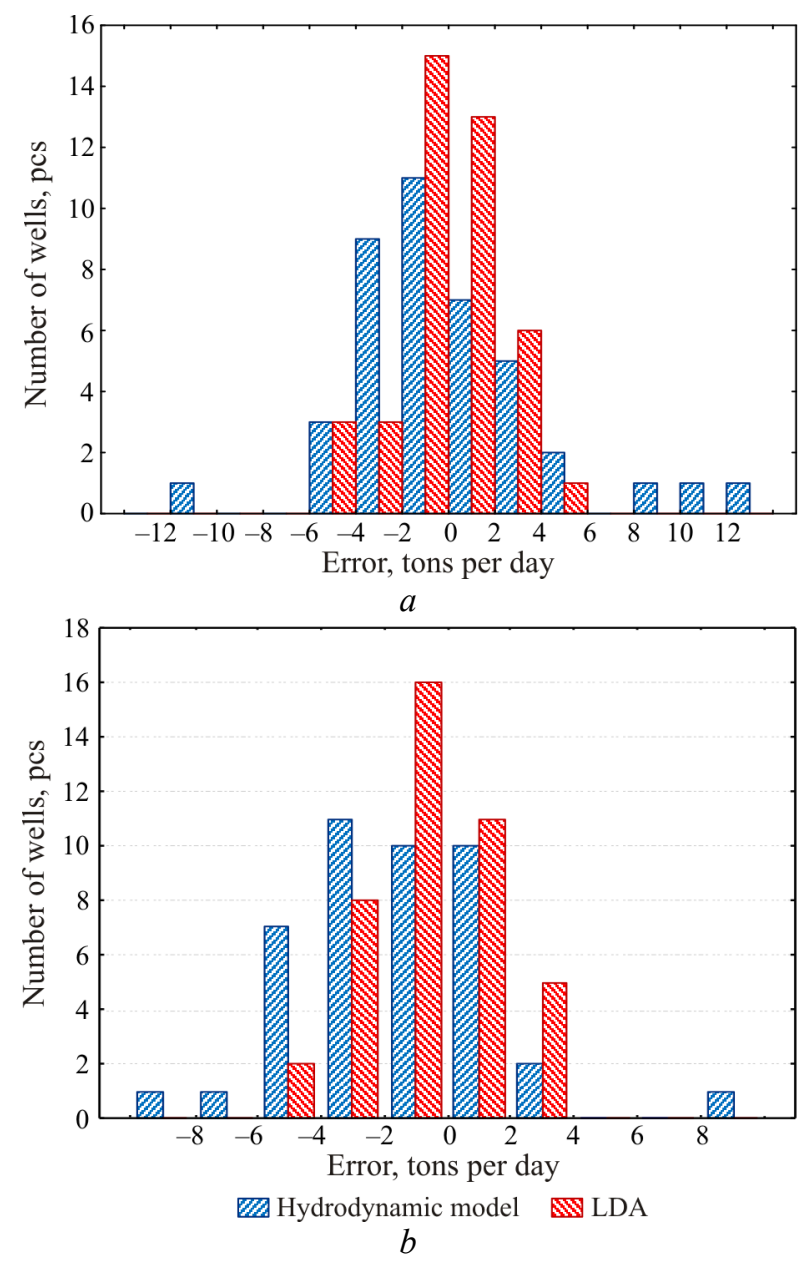

Fig. 5. Forecasted value errors compared with the actual data for the training $(a)$ and validation $(b)$ samples. $T$ formation

The error distribution range of the standard currently used methodology (see Fig. 5, a) is materially broader, ranging from -10 to +28 tons per day, while the number of forecasts with the minimal error (from -2 to 2 tons per day) is significantly less than 18 wells ( $44 \%)$. There were 7 wells ( $17 \%$ of the total number of wells) falling in the disparity interval of over 4 tons per day.

To control the forecast results, an additional estimate of the errors for the validation sampling was performed, which included the calculation of $\Delta q_{\mathrm{n}}$ values for the wells not involved in the development of a statistical model. Those were the wells than underwent the acid treatment prior to the radial drilling. Considering the adjustment explained above ( 0.8 tons per day), the actual data were compared to the forecasted values for the wells of the validation sampling. The disparities in the actual and forecasted values of $\Delta q_{\mathrm{n}}$, estimated according to the LDA method the hydrodynamic model calculations for the validation sample are provided in Fig. 5, $b$.

According to the method proposed above, the maximum number of disparities between the actual and forecasted $\Delta q_{\mathrm{n}}$ values(27 wells) fall in the range from -2 to 2 tons per day, while the maximum error ranges from -6 to +4 tons per day. The class with the disparity of over 2 tons per day included 15 wells with only 2 of them falling in the range of disparities exceeding 4 tons per day (see Fig. 5, $b$ ). The results of the comparison of the estimations based on the LDA statistical method for the T-formation should be admitted to be very good.

When compared to the actual results of the hydrodynamic modelling-based standard forecast method, the disparity range significantly expands (from -20 to +8 tons per day), with an evident tendency to overstate the projected production for the previously acid-treated wells. The minimal disparity interval (from -2 to +2 tons per day) includes 20 wells, which is much worse than fo the LDA-based forecast. The disparities exceeding 4 tons per day relate to 10 wells (compared to 2 wells found with the LDA method), with the three well interventions of which showing the disparity over 6 tons per day (see Fig. 5, $b$ ).

Thus, the comparison of disparities for the LDA-based and standard methods performed on the Tournaisian reservoirs of the platform part of the Perm Region shows a significantly higher efficiency of the former. The statistical approach significantly improves the accuracy of the oil production growth forecast for the first year after the radial drilling. The developed forecasted statistical models assessing the efficiency of the radial drilling technology were provided to an oilproducing company.

\section{Conclusion}

1. The paper provides a characteristic of the Tournaisian deposits of the platform part of the Perm Region. The reservoirs are characterized by high heterogeneity of the geological section, low thickness and, as a rule, relatively low well productivity.

2. The efficiency of the acid treatment and radial drilling methods for the Tournaisian formations of the Perm Region fields was compared. The efficiency of the radial drilling technology was found to be significantly higher than that of the acid treatment, which is statistically confirmed. 
3. A graph showing the dynamics of the effect decline depending on the radial drilling technology for the Tournaisian formations of the Perm Region was developed.

4. The advantages and disadvantages of radial drilling technology have been analyzed. Among the key advantages of the technology are the relatively low cost of the intervention and generally satisfactory growth of oil production. The key drawbacks include the impossibility to control the channel trajectory during drilling and unstable effect due to the lack of formalized applicability criteria.

5. The radial drilling technology efficiency forecasting methods were analysed with the selection of the LDA-based statistical method being substantiated. The main geotechnical parameters influencing the increment of oil production during the first year after the radial drilling were identified.

6. A forecast model for the evaluation of the incremental oil production for the first year after the radial drilling was developed. The developed method was tested on the wells of the training and validation samples. The forecasts of the radial drilling efficiency based on the statistical approach were concluded to be more accurate as compared to the standard method.

\section{References}

1. Berg S., Armstrong R., Ott H. et al. Multiphase flow in porous rock imaged under dynamic flow conditions with fast X-ray computed microtomography. Petrophysics, 2014, vol. 55, no.4, pp.304-312.

2. Galkin S.V., $\quad$ Efimov A.A., Krivoshchekov S.N., Savitskiy Ya.V., Cherepanov S.S. X-ray tomography in petrophysical studies of core samples from oil and gas fields. Russian Geology and Geophysics, 2015, no.5, pp.782-792. DOI: 10.1016/j.rgg.2015.04.009

3. Machado A.C., Oliveira T.J.L., Cruz F.B., Lopes R.T., Lima I. X-ray microtomography of hydrochloric acid propagation in carbonate rocks. Applied Radiation and Isotopes, 2015, vol.96, pp.129-134. DOI: 10.1016/j.apradiso.2014.10.027

4. Alireza Safari, Mojtaba Moradi Dowlatabad, Ali Hassani, Fariborz Rashidi Numerical simulation and Xray imaging validation of wormhole propagation during acid core-flood experiments in a carbonate gas reservoir. Journal of Natural Gas Science and Engineering, 2016, vol.30, pp.539-547. DOI: 10.1016/j.jngse.2016.02.036
5. Efimov A.A., Galkin S.V., Savitckii Ia.V., Galkin V.I. Estimation of heterogeneity of oil \& gas field carbonate reservoirs by means of computer simulation of core x-ray tomography data. Ecology, Environment and Conservation, 2015, vol.21, pp.79-85.

6. Efimov A.A., Savitckii Ia.V., Galkin S.V., Shapiro S. Experience of study of core from carbonate deposits by X-ray tomography. Perm Journal of Petroleum and Mining Engineering, 2016, vol.15, no.18, pp.23-32. DOI: 10.15593/2224-9923/2016.18.3

7. Arns C.H., Bauget F., Limaye A. et al. Porescale characterization of carbonates using X-ray microtomography. Society of Petroleum Engineers Journal, 2005, vol.10, no.4, pp.475-484. DOI: 10.2118/90368-PA

8. Cherepanov S.S., Ponomareva I.N., Erofeev A.A., Galkin S.V. Opredelenie parametrov treshchinovatosti porod na osnove kompleksnogo analiza dannykh izucheniia kerna, gidrodinamicheskikh i geofizicheskikh issledovanii skvazhin [Determination of rock fracturing parameters based on a comprehensive analysis of core study data, hydrodynamic and geophysical well surveys]. Oil industry, 2014, no.2, pp.94-96.

9. Cherepanov S.S., Chumakov G.N., Galkin S.V. Vozmozhnosti ucheta treshchinovatosti kollektorov pri geologo-gidrodinamicheskom modelirovanii razrabotki zalezhei $\mathrm{s}$ zavodneniem plastov [Possibilities for taking into account reservoir fracture during geological and hydrodynamic modeling of reservoir development with waterflooding]. Oilfield engineering, 2016, no.8, pp.5-8.

10. Gusakov V.N., Kashtanova L.E., Nazarova S.V., Tiugaeva E.S., Kalimullina G.Z., Voloshin A.I. Planirovanie obrabotki prizaboinykh zon dobyvaiushchikh skvazhin na mestorozhdenii Varadero (Kuba) [Planning for treatment of bottomhole zones of production wells in the Varadero field (Cuba)]. Oil industry, 2017, no.12, pp.126-131. DOI: 10.24887/0028-2448-2017-12-126-130

11. Iliushin P.Iu., Rakhimzianov R.M., Solov'ev D.Iu., Kolychev I.Iu. Analysis of well intervention aimed at oil production enhancement in the Perm krai's fields. Perm Journal of Petroleum and Mining Engineering, 2015, vol.14, no.15, pp.81-89. DOI: $10.15593 / 2224-9923 / 2015.15 .9$

12. Novokreshchennykh D.V., Raspopov A.V. effektivnost realizatsii tekhnologii radialnogo bureniia i matrichnykh kislotnykh obrabotok karbonatnykh kollektorov mestorozhdenii Permskogo kraia 
[Efficiency of the implementation of radial drilling technology and matrix acid treatments of carbonate reservoirs of Perm Territory deposits]. Oil industry, 2016, no.4, pp.118-121.

13. Kochnev A.A. Analiz effektivnosti tekhnologii radialnogo bureniia na primere mestorozhdenii Permskogo kraia [Analysis of the effectiveness of radial drilling technology as an example of deposits in the Perm region]. Problemy razrabotki mestorozhdenii uglevodorodnykh i rudnykh poleznykh iskopaemykh. Perm, 2017, no.1, pp.30-33.

14. Asilbekov B.K., Zhapbasbaev U.K., Kabdulov S.Z. Modelirovanie povysheniia nefteotdachi plastov sposobom radialnogo bureniia [Modeling enhanced oil recovery by radial drilling]. Vestnik KBTU, 2007, no.3, pp.7-13.

15. Martiushev D.A. Laboratornye issledovaniia kislotnykh sostavov dlia obrabotki kollektorov, kharakterizuiushchikhsia razlichnoi karbonatnostiu i strukturoi pustotnogo prostranstva gornykh porod [Laboratory studies of acid compositions for treating reservoirs characterized by various carbonates and the structure of the void space of rocks]. Izvestiia Tomskogo politekhnicheskogo universiteta. Inzhiniring georesursov, 2018, vol.329, no.4, pp.6-12.

16. Wang H., Liao X., Zhao X. Study of tight oil reservoir flow regimes in different treated horizontal well. Journal of the Energy Institute, 2015, vol.88, iss.2, pp.198-204. DOI: 10.1016/j.joei.2014.05.002

17. Jianchun Guo, Huifeng Liu, Yuanqiang Zhu, Yuxuan Liu Effects of acid-rock reaction heat on fluid temperature profile in fracture during acid fracturing in carbonate reservoirs. Journal of Petroleum Science and Engineering, 2014, vol.122, pp.31-37. DOI: 10.1016/j.petrol.2014.08.016

18. Piyang Liu, Jun Yao, Gary Douglas Couples, Jingsheng Ma, Hai Sun. Modeling and simulation of wormhole formation during acidization of fractured carbonate rocks. Journal of Petroleum Science and Engineering, 2017, vol.154, pp.284-301. DOI: 10.1016/j.petrol.2017.04.040

19. Ghommem M., Zhao W., Dyer S., Qiu X., Brady D. Carbonate aciding: Modeling, analysis, and characterization of wormhole formation and propagation. Journal of Petroleum Science and Engineering, 2015, vol.131, pp.18-33. DOI: 10.1016/j.petrol.2015.04.021

20. Snoeck Ch., Pellegrini M. Comparing bioapatite carbonate pre-treatments or isotopic measurements. Part 1. Impact on structure and chemical composition.
Chemical Geology, 2015, vol.417, pp.394-403. DOI: 10.1016/j.chemgeo.2015.10.004

21. Paveleva O.N., Popova Zh.S. Analiz effektivnosti primeneniia usovershenstvovannoi tekhnologii bureniia glubokikh radialnykh kanalov na Vakhitovskom mestorozhdenii [Analysis of the effectiveness of the application of advanced technology for drilling deep radial channels at the Vakhitovsky field]. Geologiia $i$ neftegazonosnost Zapadno-Sibirskogo megabasseina (opyt, innovatsii). Materialy desiatoi mezhdunarodnoi nauchnotekhnicheskoi konferentsii (posviashchennoi 60-letiiu Tiumenskogo industrialnogo universiteta). Tiumen, 2016, pp.112-115.

22. Martiushev D.A., Ponomareva I.N. Issledovanie osobennostei vyrabotki zapasov treshchinnoporovykh kollektorov $\mathrm{s}$ ispolzovaniem dannykh gidrodinamicheskikh issledovanii skvazhin [Study of the features of the development of reserves of crackpore reservoirs using data from hydrodynamic studies of wells]. Oil industry, 2017, no.10, pp.102-104. DOI: $10.24887 / 0028-2448-2017-10-102-104$

23. Martiushev D.A., Iliushin P.Iu. Express assessment of the interaction between the production and injection wells in the Tournaisian-Famennian deposits of Ozernoe field. Perm Journal of Petroleum and Mining Engineering, 2016, vol.15, no.18, pp.33-41. DOI: $10.15593 / 2224-9923 / 2016.18 .4$

24. Mordvinov V.A., Martiushev D.A., Puzikov V.I. Otsenka vliianiia estestvennoi treshchinovatosti kollektora na dinamiku produkttivnosti dobyvaiushchikh skvazhin slozhnopostroennoi neftianoi zalezhi [Assessment of the effect of natural fracturing of the reservoir on the dynamics of the productivity of producing wells of a complex oil reservoir]. Oil industry, 2014, no.11, pp.120-122.

25. Cherepanov S.S., Martiushev D.A., Ponomareva I.N. Otsenka filtratsionno-emkostnykh svoistv treshchinovatykh karbonatnykh kollektorov mestorozhdenii preduralskogo kraevogo progiba [Assessment of the filtrationcapacitive properties of fractured carbonate reservoirs of deposits of the Ural marginal deflection]. Oil industry, 2013, no.3, pp.62-65.

26. Shamov N.A., Liagov A.V., Panteleev D.V., Vasilev A.V., Liagova M.A., Liagov I.A., Nazarov S.V., Aseev E.G. Tekhnika i tekhnologiia sozdaniia sverkhglubokikh perforatsionnykh kanalov [Technique and technology for creating 
ultra-deep perforation channels]. Neftegazovoe delo, 2012 no.2, pp.131-174.

27. Djebbar T., Erle C. Donaldson petrophysics: Theory and practice of measuring reservoir rock and fluid transport properties. 2nd ed. Elsevier, 2004, 889 p.

28. Tiab D., Donaldson E.C. Petrophysics: Theory and practice of measuring reservoir rock and fluid transport properties. 2nd ed. Elsevier, 2004, 889 p.

29. Bortolan Neto L., Kotousov A. Residual opening of hydraulic fractures filled with compressible proppant. International Journal of Rock Mechanics and Mining Sciences, 2013, no.61, pp.223-230. DOI: 10.1016/j.ijrmms.2013.02.012

30. Warren J.E., Root P.J. The behavior of naturally fractured reservoirs. Soc. Petrol. Eng. J., 1963, vol.3, iss.3, pp.245-255. DOI: $10.2118 / 426-\mathrm{PA}$

31. Kochnev A.A., Zotikov V.I., Galkin S.V. Analiz vliianiia geologo-tekhnologicheskikh pokazatelei na effektivnost tekhnologii radialnogo bureniia na primere ekspluatatsionnykh obektov Permskogo kraia [Analysis of the influence of geological and technological indicators on the effectiveness of radial drilling technology by the example of operational facilities in the Perm Territory]. Izvestiia Tomskogo politekhnicheskogo universiteta. Inzhiniring georesursov, 2018, vol.329, no.12, pp.20-29.

32. Zongxiao Ren, Ruifeng Yan, Xing Huang, Wenqiang Liu, Zhan Qu. The transient pressure behavior model of multiple horizontal wells with complex fracture networks in tight oil reservoir. Journal of Petroleum Science and Engineering, 2019, vol.173, pp.650-665. DOI: $10.1016 /$ j.petrol.2018.10.029

33. Wei Luo, Hai-Tao Li, Yong-Qing Wang, JunChao Wang. A new semi-analytical model for predicting the performance of horizontal wells completed by inflow control devices in bottom-water reservoirs. Journal of Natural Gas Science and Engineering, 2015, vol.27, part 3, pp.1328-1339. DOI: $10.1016 /$ j.jngse.2015.03.001

34. Hamidreza Shahverdi, Mehran Sohrabi. A mechanistic model for prediction of three-phase flow in petroleum reservoirs. Journal of Petroleum Science and Engineering, 2017, vol.157, pp.507-518. DOI: 10.1016/j.petrol.2017.06.073

35. Pulok Kanti Deb, Farhana Akter, Syed Ahmad Imtiaz, M. Enamul Hossain. Nonlinearity and solution techniques in reservoir simulation: A review. Journal of Natural Gas Science and Engineering, 2017, vol.46, pp.845-864. DOI: 10.1016/j.jngse.2017.07.031

36. Wei Pang, Dechun Chen, Zhongping Zhang, Lifu Jiang, Bing Wang. Segmentally variable density perforation optimization model for horizontal wells in heterogeneous reservoirs. Petroleum Exploration and Development, 2012, vol.39, iss.2, pp.230-238. DOI: 10.1016/S1876-3804(12)60036-6

37. Ghahri P., Jamiolahmadi M., Alatefi E., Wilkinson D., Hamidi H. A new and simple model for the prediction of horizontal well productivity in gas condensate reservoirs. Fuel, 2018, vol.223, pp.431-450. DOI: 10.1016/j.fuel.2018.02.022

38. Khan R.A., Awotunde A.A. Determination of vertical/horizontal well type from generalized field development optimization. Journal of Petroleum Science and Engineering, 2018, vol.162, pp.652-665. DOI: 10.1016/j.petrol.2017.10.083

39. Dowlatabad M.M., Jamiolahmady M. New approach for predicting multiple fractured horizontal wells performance in tight reservoirs. Journal of Petroleum Science and Engineering, 2018, vol.162, pp.233-243. DOI: 10.1016/j.petrol.2017.12.040

40. Losi G., Arnone D., Correra S., Poesio P. Modelling and statistical analysis of high viscosity oil/air slug flow characteristics in a small diameter horizontal pipe. Chemical Engineering Science, 2016, vol.148, pp.190-02. DOI: 10.1016/j.ces.2016.04.005

41. Galkin V.I., Ponomareva I.N., Repina V.A. Study of oil recovery from reservoirs of different void types with use of multidimensional statistical analysis. Perm Journal of Petroleum and Mining Engineering, 2016, no.19, pp.145-154. DOI: $10.15593 / 2224-9923 / 2016.19 .5$

42. Chumakov G.N., Zotikov V.I., Kolychev I.Iu., Galkin S.V. Analiz effektivnosti primeneniia tsiklicheskoi zakachki zhidkosti na mestorozhdeniiakh s razlichnymi geologo-tekhnologicheskimi usloviiami [Analysis of the effectiveness of the use of cyclic fluid injection in fields with various geological and technological conditions]. Oil industry, 2014, no.9, pp.96-99.

\section{Библиографический список}

1. Multiphase flow in porous rock imaged under dynamic flow conditions with fast X-ray computed microtomography / S. Berg, R. Armstrong, H. Ott [et al.] // Petrophysics. 2014. - Vol. 55, № 4. - P. 304-312. 
2. X-ray tomography in petrophysical studies of core samples from oil and gas fields / S.V. Galkin, A.A. Efimov, S.N. Krivoshchekov, Ya.V. Savitskiy, S.S. Cherepanov // Russian Geology and Geophysics. - 2015. - № 5. - P.782-792. DOI: 10.1016/j.rgg.2015.04.009

3. X-ray microtomography of hydrochloric acid propagation in carbonate rocks / A.C. Machado, T.J.L. Oliveira, F.B. Cruz, R.T. Lopes, I. Lima // Applied Radiation and Isotopes. - 2015. - Vol. 96. P. 129-134. DOI: 10.1016/j.apradiso.2014.10.027

4. Numerical simulation and Xray imaging validation of wormhole propagation during acid coreflood experiments in a carbonate gas reservoir / Alireza Safari, Mojtaba Moradi Dowlatabad, Ali Hassani, Fariborz Rashidi // Journal of Natural Gas Science and Engineering. - 2016. - Vol. 30. P. 539-547 DOI: 10.1016/j.jngse.2016.02.036

5. Estimation of heterogeneity of oil \& gas field carbonate reservoirs by means of computer simulation of core x-ray tomography data / A.A. Efimov, S.V. Galkin, Ia.V. Savitckii, V.I. Galkin // Ecology, Environment and Conservation. - 2015. Vol. 21. - P. 79-85.

6. Опыт исследования керна карбонатных отложений методом рентгеновской томографии / А.А. Ефимов, Я.В. Савицкий, С.В. Галкин, С. Шапиро // Вестник Пермского национального исследовательского политехнического университета. Геология. Нефтегазовое и горное дело. - 2016. - Т. 15, № 18. - С. 23-32. DOI: $10.15593 / 2224-9923 / 2016.18 .3$

7. Pore-scale characterization of carbonates using X-ray Microtomography / C.H. Arns, F. Bauget, A. Limaye [et al.] // Society of Petroleum Engineers Journal. - 2005. - Vol. 10, № 4. - P. 475-484. DOI: $10.2118 / 90368-P A$

8. Определение параметров трещиноватости пород на основе комплексного анализа данных изучения керна, гидродинамических и геофизических исследований скважин / С.С. Черепанов, И.Н. Пономарева, А.А. Ерофеев, С.В. Галкин // Нефтяное хозяйство. - 2014. № 2. - C. 94-96.

9. Черепанов С.С., Чумаков Г.Н., Галкин С.В. Возможности учета трещиноватости коллекторов при геолого-гидродинамическом моделировании разработки залежей с заводнением пластов // Нефтепромысловое дело. - 2016. - № 8. - С. 5-8.

10. Планирование обработки призабойных зон добывающих скважин на месторож- дении Варадеро (Куба) / В.Н. Гусаков, Л.Е. Каштанова, С.В. Назарова, Е.С. Тюгаева, Г.З. Калимуллина, А.И. Волошин // Нефтяное хозяйство. - 2017. - № 12. - С. 126-131. DOI: $10.24887 / 0028-2448-2017-12-126-130$

11. Анализ проведения геолого-технических мероприятий по увеличению продуктивности добывающих скважин на нефтяных месторождениях Пермского края / П.Ю. Илюшин, Р.М. Рахимзянов, Д.Ю. Соловьев, И.Ю. Колычев // Вестник Пермского национального исследовательского политехнического университета. Геология. Нефтегазовое и горное дело. 2015 . - T. 14, № 15 . - C. 81-89. DOI: $10.15593 / 2224-9923 / 2015.15 .9$

12. Новокрещенных Д.В., Распопов А.В. Эффективность реализации технологии радиального бурения и матричных кислотных обработок карбонатных коллекторов месторождений Пермского края // Нефтяное хозяйство. - 2016. - № 4. - С. 118-121.

13. Кочнев А.А. Анализ эффективности технологии радиального бурения на примере месторождений Пермского края // Проблемы разработки месторождений углеводородных и рудных полезных ископаемых. - Пермь, 2017. - № 1. - С. 30-33.

14. Асилбеков Б.К., Жапбасбаев У.К., Кабдулов С.3. Моделирование повышения нефтеотдачи пластов способом радиального бурения // Вестник КБТУ. - 2007. - № 3. C. $7-13$.

15. Мартюшев Д.А. Лабораторные исследования кислотных составов для обработки коллекторов, характеризующихся различной карбонатностью и структурой пустотного пространства горных пород // Известия Томского политехнического университета. Инжиниринг георесурсов. - 2018. - Т. 329, № 4. - С. 6-12.

16. Wang H., Liao X., Zhao X. Study of tight oil reservoir flow regimes in different treated horizontal well // Journal of the Energy Institute. 2015. - Vol. 88, iss. 2. - P. 198-204. DOI: $10.1016 /$ j.joei.2014.05.002

17. Effects of acid-rock reaction heat on fluid temperature profile in fracture during acid fracturing in carbonate reservoirs / Jianchun Guo, Huifeng Liu, Yuanqiang Zhu, Yuxuan Liu // Journal of Petroleum Science and Engineering. - 2014. - Vol. 122. - P. 31-37. DOI: $10.1016 /$ j.petrol.2014.08.016 
18. Modeling and simulation of wormhole formation during acidization of fractured carbonate rocks / Piyang Liu, Jun Yao, Gary Douglas Couples, Jingsheng Ma, Hai Sun // Journal of Petroleum Science and Engineering. - 2017. - Vol. 154. - P. 284-301. DOI: $10.1016 /$ j.petrol.2017.04.040

19. Carbonate aciding: Modeling, analysis, and characterization of wormhole formation and propagation / M. Ghommem, W. Zhao, S. Dyer, Xiangdong Qiu, D. Brady // Journal of Petroleum Science and Engineering. - 2015. - Vol. 131. P. 18-33. DOI: 10.1016/j.petrol.2015.04.021

20. Snoeck Ch., Pellegrini M. Comparing bioapatite carbonate pre-treatments or isotopic measurements: P. 1. Impact on structure and chemical composition // Chemical Geology. - 2015. - Vol. 417. - P. 394-403. DOI: $10.1016 /$ j.chemgeo.2015.10.004

21. Павельева О.Н., Попова Ж.С. Анализ эффективности применения усовершенствованной технологии бурения глубоких радиальных каналов на Вахитовском месторождении // Геология и нефтегазоносность Западно-Сибирского мегабассейна (опыт, инновации): материалы десятой международной научно-технической конференции (посвященной 60-летию Тюменского индустриального университета). - Тюмень, 2016. - С. 112-115.

22. Мартюшев Д.А., Пономарева И.Н. Исследование особенностей выработки запасов трещинно-поровых коллекторов с использованием данных гидродинамических исследований скважин // Нефтяное хозяйство. - 2017. - № 10. - С. 102-104. DOI: 10.24887/0028-2448-2017-10-102-104

23. Мартюшев Д.А., Илюшин П.Ю. Экспрессоценка взаимодействия между добывающими и нагнетательными скважинами на турнефаменской залежи Озерного месторождения // Вестник Пермского национального исследовательского политехнического университета. Геология. Нефтегазовое и горное дело. - 2016. - Т. 15, № 18. C. 33-41. DOI: 10.15593/2224-9923/2016.18.4

24. Мордвинов В.А., Мартюшев Д.А., Пузиков В.И. Оценка влияния естественной трещиноватости коллектора на динамику продуктивности добывающих скважин сложнопостроенной нефтяной залежи // Нефтяное хозяйство. - 2014. - № 11. - С. 120-122.

25. Черепанов С.С., Мартюшев Д.А., Пономарева И.Н. Оценка фильтрационно- емкостных свойств трещиноватых карбонатных коллекторов месторождений предуральского краевого прогиба // Нефтяное хозяйство. - 2013. № 3. - С. 62-65.

26. Техника и технология создания сверхглубоких перфорационных каналов / Н.А. Шамов, А.В. Лягов, Д.В. Пантелеев, А.В. Васильев, М.А. Лягова, И.А. Лягов, С.В. Назаров, Е.Г. Асеев // Нефтегазовое дело. - 2012. № 2. - C. 131-174.

27. Djebbar T., Erle C. Donaldson petrophysics: Theory and practice of measuring reservoir rock and fluid transport properties. - 2nd ed. - Elsevier, 2004. -889 p.

28. Tiab D., Donaldson E.C. Petrophysics: Theory and practice of measuring reservoir rock and fluid transport properties. - 2nd ed. - Elsevier, 2004. -889 p.

29. Bortolan Neto L., Kotousov A. Residual opening of hydraulic fractures filled with compressible proppant // International Journal of Rock Mechanics and Mining Sciences. - 2013. - № 61. - P. 223-230. DOI: $10.1016 /$ j.ijrmms.2013.02.012

30. Warren J.E., Root P.J. The behavior of naturally fractured reservoirs // Soc. Petrol. Eng. J. 1963. - Vol. 3, iss. 3. - P. 245-255. DOI: $10.2118 / 426-\mathrm{PA}$

31. Кочнев А.А., Зотиков В.И., Галкин С.В. Анализ влияния геолого-технологических показателей на эффективность технологии радиального бурения на примере эксплуатационных объектов Пермского края // Известия Томского политехнического университета. Инжиниринг георесурсов - 2018. - Т. 329, № 12. - C. 20-29.

32. The transient pressure behavior model of multiple horizontal wells with complex fracture networks in tight oil reservoir / Zongxiao Ren, Ruifeng Yan, Xing Huang, Wenqiang Liu, Zhan $\mathrm{Qu} / /$ Journal of Petroleum Science and Engineering. - 2019. - Vol. 173. - P. 650-665. DOI: $10.1016 /$ j.petrol.2018.10.029

33. A new semi-analytical model for predicting the performance of horizontal wells completed by inflow control devices in bottom-water reservoirs / Wei Luo, Hai-Tao Li, Yong-Qing Wang, Jun-Chao Wang // Journal of Natural Gas Science and Engineering. - 2015. - Vol. 27, part 3. P. 1328-1339. DOI: 10.1016/j.jngse.2015.03.001

34. Hamidreza Shahverdi, Mehran Sohrabi. A mechanistic model for prediction of three-phase 
flow in petroleum reservoirs // Journal of Petroleum Science and Engineering. - 2017. - Vol.157. P. 507-518. DOI: 10.1016/j.petrol.2017.06.073

35. Nonlinearity and solution techniques in reservoir simulation: A review / Pulok Kanti Deb, Farhana Akter, Syed Ahmad Imtiaz, M. Enamul Hossain // Journal of Natural Gas Science and Engineering. - 2017. - Vol. 46. - P. 845-864. DOI: $10.1016 /$ j.jngse.2017.07.031

36. Segmentally variable density perforation optimization model for horizontal wells in heterogeneous reservoirs / Wei Pang, Dechun Chen, Zhongping Zhang, Lifu Jiang, Bing Wang // Petroleum Exploration and Development. 2012. - Vol. 39, iss. 2. - P. 230-238. DOI: $10.1016 / \mathrm{S} 1876-3804(12) 60036-6$

37. A new and simple model for the predicttion of horizontal well productivity in gas condensate reservoirs / P. Ghahri, M. Jamiolahmadi, E. Alatefi, D. Wilkinson, H. Hamidi // Fuel. - 2018. - Vol. 223. - P. 431-450. DOI: $10.1016 /$ j.fuel.2018.02.022

38. Khan R.A., Awotunde A.A. Determination of vertical/horizontal well type from generalized field development optimization // Journal of Petroleum Science and Engineering. - 2018. - Vol. 162. P. 652-665. DOI: 10.1016/j.petrol.2017.10.083
39. Dowlatabad M.M., Jamiolahmady M. New approach for predicting multiple fractured horizontal wells performance in tight reservoirs // Journal of Petroleum Science and Engineering. - 2018. - Vol. 162. - P. 233-243. DOI: 10.1016/j.petrol.2017.12.040

40. Modelling and statistical analysis of high viscosity oil/air slug flow characteristics in a small diameter horizontal pipe / G. Losi, D. Arnone, S. Correra, P. Poesio // Chemical Engineering Science. - 2016. - Vol. 148. - P. 190-202. DOI: $10.1016 /$ j.ces.2016.04.005

41. Галкин В.И., Пономарева И.Н., Репина В.А. Исследование процесса нефтеизвлечения в коллекторах различного типа пустотности с использованием многомерного статистического анализа // Вестник Пермского национального исследовательского политехнического университета. Геология. Нефтегазовое и горное дело. - 2016. - № 19. - С. 145-154. DOI: $10.15593 / 2224-9923 / 2016.19 .5$

42. Анализ эффективности применения циклической закачки жидкости на месторождениях с различными геолого-технологическими условиями / Г.Н. Чумаков, В.И. Зотиков, И.Ю. Колычев, С.В. Галкин // Нефтяное хозяйство. - 2014. - № 9. - С. 96-99.

Please cite this article in English as:

Kochnev A.A., Galkin S.V. Estimated efficiency of radial drilling technology for Tournaisian production zones of the Perm Region. Perm Journal of Petroleum and Mining Engineering, 2019, vol.19, no.3, pp.263-274. DOI: 10.15593/2224-9923/2019.3.6

Просьба ссылаться на эту статью в русскоязычных источниках следующим образом:

Кочнев А.А., Галкин С.В. Прогнозная оценка эффективности технологии радиального бурения для турнейских эксплуатационных объектов платформенной части Пермского края // Вестник Пермского национального исследовательского политехнического университета. Геология. Нефтегазовое и горное дело. - 2019. - Т.19, №3. C.263-274. DOI: 10.15593/2224-9923/2019.3.6 